\section{H. ARENDT Y TH. W. ADORNO: PENSAR FRENTE A LA} BARBARIE

\author{
José A. Zamora \\ Instituto de Filosofía - CCHS/CSIC
}

\section{H. ARENDT AND TH. W. ADORNO: THINKING AGAINST BARBARITY}

\begin{abstract}
Two of the most important thinkers of the twentieth century, Hannah Arendt and Theodor W. Adorno (whose thoughts tried to deal with the most extreme horror of that century, Auschwitz) refused to communicate or even to take into consideration each other's works. This article attempts to bring them into dialogue from the point of view of what constituted the core of their work: thinking against the barbarity of the extermination camps - thinking and acting so that such barbarity is not repeated. After presenting the form in which both philosophers think the singularity of the genocide and the links with the historical and social processes that made it possible, the article tries to analyze their underlying differences, which have to do with two irreconcilable theoretical approaches.
\end{abstract}

KEY WORDS: Arendt; Adorno; Auschwitz; radical evil; banality of evil; anti-Semitism; modernity; capitalism; total domination.

\section{INTRODUCCIÓN}

Existen paralelismos innegables en la vida de Arendt y Adorno. Nacidos con muy pocos años de diferencia, se formaron en un clima intelectual bastante similar a comienzos del siglo XX en la República de Weimar. Ambos pertenecían a familias judías o medio judías asimiladas. Por su condición de judios los dos tuvieron que abandonar la Alemania nazi, formaron parte del exilio intelectual judío en los EEUU y se constituyeron en observadores extremadamente críticos del proceso de reconstrucción alemana y de elaboración del pasado nazi tras la guerra'. Pero quizás lo decisivo a la hora de comparar su pensamiento sea que ambos hicieron de la confrontación con la barbarie que se había materializado en medio de la civilización el reto intelectual y vital fundamental que marcaría su existencia y trayectoria intelectual. En la obra de estos dos intelectuales es reconocible un núcleo que determina todo su pensamiento: pensar frente a la barbarie de los campos de exterminio - pensar y actuar para que esa barbarie no se repita.
RESUMEN: Dos de los pensadores más importantes del siglo $\mathrm{XX}$, Hannah Arendt y Theodor W. Adorno, cuyo pensamiento pretendió medirse con el horror más extremo que conoció dicho siglo -Auschwitz-, se negaron a comunicarse y a considerar la obra del otro. Este artículo intenta ponerlos en diálogo a partir de lo que constituyó el núcleo de su obra: pensar frente a la barbarie de los campos de exterminio - pensar y actuar para que esa barbarie no se repita. Tras presentar la forma en que ambos piensan la singularidad del genocidio y los vínculos con los procesos históricos y sociales que lo hicieron posible, trata de analizar las diferencias de fondo, aquéllas que tienen que ver con dos enfoques teóricos irreconciliables.

PALABRAS CLAVE: Arendt; Adorno; Auschwitz; mal radical; banalidad del mal; antisemitismo; modernidad; capitalismo; dominación total.

Dada la coincidencia en este punto de partida, no deja de sorprender el incuestionable hecho de que ninguno de los dos tomara en consideración la obra del otro, de su negativa al diálogo o a la recepción mutua. ¿Se debió a motivos puramente personales o biográficos? Por lo general éstos son los que primero saltan a vista y los que se suelen tener en cuenta. Arendt achacaba a Adorno el fracaso del intento de habilitación académica de su primer marido Günter Stern (Günter Anders) y consideraba inaceptable e irritante el trato que según ella recibía Walter Benjamin en el exilio francés de parte de Instituto de Investigación Social en Nueva York. Su suspicacia frente a lo que éstos pudieran hacer con los manuscritos de Benjamin, entre ellos el texto con las Tesis sobre el concepto de historia, que la propia Arendt debió entregar a Adorno por encargo expreso de su autor, su denuncia en el periódico estudiantil Diskurs de los supuestos intentos de Adorno de adaptación a la Alemania nazi como crítico musical antes de su exilio, la controversia en torno a la primera edición de las obras de Benjamin, que motivó su única correspondencia conocida, y la acusación a Adorno de urdir campañas difamatorias contra su maestro Heidegger, son algunos de los episodios 
de esta historia de desencuentros ${ }^{2}$. Frente a esta animosidad y desprecio de Arendt hacia la persona de Adorno, en él sólo encontramos ignorancia e indiferencia respecto a una pensadora cuyos ascendentes intelectuales alemanes seguramente le hacian aparecer ante sus ojos como conservadora y filosóficamente irrelevante.

Más allá de estos desencuentros personales no puede ignorarse que los horizontes intelectuales de referencia en ambos autores son completamente divergentes. Sobre esto volveré más adelante. También es necesario constatar la desigual recepción de la filosofía social de Adorno y de la teoría política de Arendt tras la Segunda Guerra Mundial. Mientras que Adorno se constituia en un referente intelectual de la izquierda europea, habría que esperar casi al final de la guerra fría para que se produjese una amplia recepción del pensamiento político de Arendt. A esto se unen las diferentes coyunturas que han propiciado un creciente debate en torno a la posible actualidad de su aportación intelectual en una hora de enorme desconcierto y agotamiento de "paradigmas", incluidos los supuestos "cambios de paradigma". Si bien en el caso de Arendt su actualidad está vinculada con la llamada "crisis del marxismo", por un lado, y de la "política", por otro (Heuer, 1997, 21), quizás en el caso de Adorno dicha actualidad esté relacionada con los intentos de una "relectura del marxismo" después del colapso del bloque soviético y de la agudización de las contradicciones del capitalismo tardío, de una parte, y con el agotamiento de lo que recibió el precipitado nombre de postmodernidad, por otra. Sin embargo, lo que nos interesa poner en el centro de nuestra comparación es la radicalidad de la mirada que ambos arrojaron sobre el horror materializado en los campos de concentración y de exterminio y la intención desesperada de desentrañar su significado para entender el mundo y la sociedad en que dicho horror había podido producirse. Este punto de coincidencia es el que justifica el esfuerzo de analizar analogías y diferencias entre ambos pensadores y de preguntarnos sobre lo que ambos nos legan como tarea para pensar nuestro presente.

Para Adorno y Arendt la catástrofe de Auschwitz supuso una quiebra civilizatoria de extraordinarias dimensiones que carecía de precedentes en la ya terrible historia humana. Ambos pusieron el acento en la singularidad de lo acontecido en los campos de exterminio, algo para lo que no existen analogías, y, sin embargo, también esta- ban convencidos de que ese acontecimiento arrojaba una penetrante luz desveladora sobre los procesos históri$\cos$, sociales, culturales y políticos que lo hicieron posible (Adorno, 1980, 268). Saber de la existencia de Auschwitz fue, tal como expresa H. Arendt, "como si el abismo se abriese" (Arendt, 2005a, 30). Se trataba de una quiebra que destruia cualquier confianza en una teleologia histórica positiva y ponía ante los ojos algo insospechado, incluso para quienes no habian sido víctimas previamente de una ingenua creencia en el progreso (Arendt, 2005a, 246). En su contingencia histórica refractaria a todo intento de integración en un esquema causal, Auschwitz, desborde tal de horror que se vuelve inexplicable por cualquier nexo, ya sea en relación con el desarrollo tecnológico y su aplicación destructiva, con la universalización de la organización burocrática de la vida social, con el sesgo autoritario de los Estados nación o con su descomposición, con el darvinismo social convertido en ideología popular, con la sustracción a la determinación moral de los procesos administrativos y de la acción de los sujetos implicados en su funcionamiento, etc. (Birulés, 2006, 42s.), Auschwitz, decimos, sin embargo, hace que muchos de esos elementos constitutivos de la modernidad o relacionados con su devenir histórico aparezcan bajo una nueva luz y manifiesten una complicidad con la catástrofe. Estos son los dos movimientos que Arendt y Adorno imponen al pensamiento ante la catástrofe de Auschwitz: analizar su singularidad irreductible y desentrañar desde ella lo universal, para intentar reconocer y combatir en lo universal las condiciones de posibilidad del horror.

\section{EL CAMPO DE EXTERMINIO: EL TOPOS DEL MAL RADICAL}

Para Arendt aquello que singulariza la dominación totalitaria, su "institución central", (Arendt, 1981, 653) son los campos de exterminio. En un ámbito separado y blindado se experimenta como en un laboratorio aquello en lo que consiste de manera esencial dicha dominación. Es el lugar en el que han sido eliminados todos los obstáculos que pudieran dificultar un perfecto funcionamiento del dominio total. En ellos se lleva a cabo un exterminio industrial, sustentado en una organización burocrática compleja, ejecutado por individuos "normales" que "hacían su trabajo" y "cumplian órdenes" y que pretendía la aniquilación de todo 
lo que caracteriza a la individualidad humana (Traverso, 2001, 84ss).

Según el concepto arendtiano que mayor difusión ha alcanzado, los campos de exterminio son la expresión del "mal radical". Un mal radical que tiene que ver, como escribe en una carta a K. Jaspers, con "hacer superfluos" a los hombres en cuanto tales (Arendt/Jaspers, 1993, 202). Esta empresa va decididamente más allá de la mera instrumentalización de aquellos que, según la definición kantiana, son fines en sí. En los campos de exterminio "el homicidio es tan impersonal como el aplastamiento de un mosquito" (Arendt, 1981, 650). Los seres humanos son degradados a puro material humano superfluo.

Según esto, la singularidad del Auschwitz no reside en el número de víctimas, tampoco en los argumentos antisemitas o racistas que esgrimieron los perpetradores, sino en el hecho de que representa una nueva forma de asesinato masivo que convierte a los congéneres en meros ejemplares desprovistos de individualidad, de aquellos rasgos que nos diferencian de los animales: la pluralidad y la espontaneidad en el pensar y el actuar. En los campos de exterminio la eliminación de seres humanos se realiza como si se tratara de eliminar a insectos molestos, "sin consideración de la persona". En el genocidio actúa una estructura funcional que abstrae de toda singularidad, una estructura volcada en su propio funcionar. "El totalitarismo -dice Arendtbusca no la dominación despótica sobre los hombres, sino un sistema en el que los hombres sean superfluos. El poder total sólo puede ser logrado y salvaguardado en un mundo de reflejos condicionados, de marionetas sin el más ligero rasgo de espontaneidad" (Arendt, 1981, 677). Esta lógica desindividualizadora no sólo afecta a las víctimas, sino también a los verdugos, cuya existencia es tan superflua como la de aquéllas (Arendt/Blumenfeld, 1995, 43). Este es el verdadero horror del mal radical: la insignificancia del ser hombre, su completa funcionalización en un proceso de aniquilación que lo convierte en puro material.

Ésta es también la razón fundamental para eliminar de la muerte todo carácter humano y personal. El "genocidio administrativo" (Verwaltungsmassenmord) convierte la muerte en un acto burocrático e industrializado. La muerte se vuelve anónima. Podemos decir que a la víctima no sólo le es arrebatada la vida, también se le arrebata la muerte. $Y$ por eso ha de ser tratada en vida como si ya no existiera, como si su existencia no importara nada. "Su muerte simplemente pone un sello sobre el hecho de que en realidad nunca habia existido" (Arendt, 1981, 671). Dado que es la existencia humana en cuanto tal la que debe ser borrada, en Auschwitz no bastaba simplemente con asesinar, se trataba de "fabricar" cadáveres y de hacerlos desaparecer ${ }^{3}$. La eliminación de todo resto era el último paso consecuente de la negación de cualquier sentido a la existencia de los aniquilados.

Esta conexión entre aniquilación y burocratización que revela la despersonalización de la muerte en los campos de exterminio permite reconocer muchos rasgos comunes en la forma de dominación administrativa (M. Weber) y el mal radical: "Los rasgos del mal radical -escribe Arendt en su Diarios filosóficos- son: 1. La ausencia de motivos y el carácter desinteresado. 2. La completa carencia de imaginación, de la que se deriva un fallo total de la compasión, ¡también de la compasión consigo mismo! 3. Coherencia de todo lo puramente lógico, sacar las últimas conclusiones a partir de las premisas previamente asumidas y mantener a raya a los otros con el argumento: quién ha dicho $A$, debe decir también B" (Arendt, 2006a/I, 124). El carácter puramente funcional de la aniquilación en los campos establece una conexión entre asesinato y lógica burocrática de enormes consecuencias. Como confiesa Arendt a Jaspers en una carta, dicho mal no procede de supuestas perversiones o de vicios morales (Arendt/Jaspers, 1993, 202), sino de la completa formalización de la aniquilación derivada de su burocratización. El procedimiento está dominado más bien por la apatía, por el cumplimento desinteresado de prescripciones y normativas. Este desinterés (Selbstlosigkeit) es el fundamento de la formalización, de la coacción fría de la lógica implacable de la deducción, de su totalización, que termina abstrayendo de los seres concretos y las relaciones, tal como suena en el término acuñado por Göring de "solución final" (Endlösung) de la cuestión judía.

Ésta es la razón de que, a pesar de la diferencias y de la interpretación de la propia Arendt, no se pueda hablar de una completa discontinuidad entre la tesis del "mal radical" y la "banalidad del mal". El vínculo entre las formas de dominación burocrática y el mal radical ponen de manifiesto hasta qué punto determinada funcionalización y formalización de las relaciones sociales, en las que los seres humanos se han vuelto superfluos en cuanto personas, maduran las 
condiciones de una aniquilación fría y funcionarial de los individuos. Los discursos secretos de Heinrich Himmler, organizador de Holocausto, son realmente reveladores en este sentido. Firmeza, resolución y dureza van de la mano de una completa carencia de sentimientos hacia los sufrimientos de los otros, que deben ser eliminados sin excesos de "crueldad" (Himmler, 1974). La certera descripción que Arendt hace de este poderoso nazi lo retrata no como un fanático lleno de crueldad, sino más bien como un pequeño burgués, como un filisteo, representante de aquellos individuos atomizados capaces de entregarlo todo para responder a cualquier amenaza de su seguridad (Arendt, 1981,524 s.). La dureza y la frialdad del genocidio administrativo (Verwaltungsmassenmord) sólo fue posible sobre la base de la apatía de quienes se pusieron al servicio de un entramado funcional que, produciendo el máximo horror, sugería el mantenimiento de la más estricta normalidad.

Nadie encarna esa normalidad de modo tan acabado como Adolf Eichmann, cuyo proceso sirvió de base a una las obras más conocidas de $\mathrm{H}$. Arendt. Lo que sorprendió a nuestra autora, por más que esta imagen haya sido posteriormente sometida a revisión (Smith, 2000), es que sus rasgos tampoco correspondian a los de un criminal, sino a los de un burócrata tan obediente como eficiente (Aren$d t, 2003,44 s$.). Esto ponía en evidencia que el genocidio había sido posible gracias a una coordinación sistémica de un conjunto de individuos que se negaban a asumir responsabilidad. El escándalo que produjo la expresión "banalidad del mal" se debió en gran medida a que se quiso ver en ella una banalización del genocidio, cuando en realidad lo que pretendía era una caracterización radical del crimen ${ }^{4}$. Presentando a Eichmann como un funcionario de la muerte, como un ingeniero social de la deportación para la aniquilación, Arendt no pretendía minimizar la dimensión del horror, sino mostrar que éste tiene que ver con la destrucción de la capacidad para pensar y juzgar (Arendt, 1971, 417), con la eliminación de toda independencia frente a la ley sancionada por el poder dominante (Arendt, 2006b).

El concepto de la "banalidad de mal" nos pone tras la pista de la cuestión fundamental que plantea la catástrofe de Auschwitz, esto es, que su ejecución se basó en el buen funcionamiento de una maquinaria burocrática y en el desempeño obediente de funciones racionalmente definidas previamente, así como en la existencia de individuos capaces de servirla sin problemas de conciencia, por más que con ello se eliminasen millones de seres humanos inocentes (Schulze, 2006, 193). Evidentemente este mal no tiene nada de banal, tampoco las condiciones que lo hicieron posible, pero fueron condiciones normalizadas, incluso para los que condenaban sin paliativos su efectos. Este vínculo entre funcionalidades normalizadas y mal extremo es lo que denuncia $\mathrm{H}$. Arendt y lo que convierte el horror en algo todavía más temible.

\section{Los orígenes de la catÁstrofe}

En su análisis de los orígenes del totalitarismo Arendt distingue los elementos de la dominación total respecto de la aparición histórica de regímenes totalitarios ${ }^{5}$. Esto le permite afirmar la existencia de dichos elementos previamente y más allá del período histórico dominado por los mencionados regímenes, que, como hemos visto, poseen un rasgo distintivo y exclusivo: los campos de exterminio. Esta caracterización también hace posible que la afirmación de singularidad irreductible de la dominación total no oculte los vínculos que ella mantiene con el mundo no totalitario, tanto desde el punto de vista de la génesis, como también desde la consideración de su posible resurgir (Arendt, 1981, 681). No existe tranquilidad alguna basada en la supuesta constatación de la ausencia de campos de exterminio. Las condiciones que hicieron posible su existencia no han desaparecido definitivamente. Nuestro mundo no es completamente diferente de aquél en el que ocurrió Auschwitz.

Considerar la singularidad y la vinculación al mismo tiempo no sólo exige reflexionar sobre lo que el "genocidio administrado" tiene de ruptura con la historia precedente y posterior, sino también atender a las continuidades y complicidades con la "normalidad" histórica. Esta es la razón de que nos encontremos con afirmaciones aparentemente contradictorias. Por un lado, Arendt afirma que la dominación totalitaria, "en su carácter sin precedentes no se puede aprehender mediante las categorias habituales del pensamiento político", se trata de un acontecimiento que "rompió la continuidad de la historia de Occidente" (Arendt, 1996, 33). Sin embargo, por otro lado, en una carta a K. Jasper, en la que le da cuenta de sus esfuerzos por limpiar la tradición filosófica occidental "de Platón 
a Nietzsche inclusive" de toda sospecha de complicidad con los elementos de las formas totalitarias de gobierno, no deja dereconocer su responsabilidad en la génesis de la catástrofe. Ésta consistiría en no haber elaborado un genuino concepto de lo político, que sólo puede ser construido desde la centralidad de la idea de pluralidad (Arendt/Jaspers, 1993, 203), cuyo contrario es el concepto de masa.

Por eso buena parte de su libro sobre Los orígenes del totalitarismo está dedicado a analizar los procesos de constitución de un nuevo tipo de sociedad: "la sociedad de masas". El antisemitismo y el imperialismo, fenómenos a los que Arendt dedica el primer y el segundo de los volúmenes de su obra, tienen enorme relevancia en cuanto que preparan la aparición de ese nuevo tipo de sociedad. El antisemitismo está directamente relacionado con la dialéctica entre el proceso general de emancipación en la modernidad y el de la emancipación judía en particular y con la disolución del individuo como sujeto de derechos. La muerte jurídica, que dejaba a millones de personas sin la protección del derecho cristalizado en los sistemas jurídicos de los Estados-Nación, es el precedente de la muerte industrial-burocrática perpetrada en los campos. Pero si la crisis de los Estados nacionales unida al crecimiento del racismo ponía en el punto de mira a las minorías étnicas o a los ciudadanos sin Estado y permitía identificarlos de modo prioritario como poblaciones a segregar y eliminar (parias), el proceso desencadenado alcanza en el Estado totalitario una dimensión universal. Potencialmente nadie estaba a salvo en él de la arbitrariedad de un poder que podía dejar sin la protección de los derechos burgueses a cualquiera. A esto se une la deriva imperialista de los Estados europeos, que Arendt considera fundamentalmente desde la perspectiva del colapso de la sociedad de clases, un colapso promovido por los burgueses a través de la supeditación del Estado al despliegue ilimitado de sus intereses económicos. El resultado es una perversa alianza del capital con la masa atomizada y amorfa cómplice con el racismo y la negación de los derechos humanos a los pueblos colonizados. Esto resultó posible por una especie de disolución moral del individuo dispuesto a sacrificar su capacidad de pensar y enjuiciar $y$, en definitiva, sus libertades políticas a la búsqueda del enriquecimiento o por una especie de disposición generalizada a someterse a formas de dominación que prometan estabilidad y orden.
Arendt considera que los movimientos totalitarios sólo son posibles en sociedades de masas (Arendt, 1981, 489), es decir, alli donde se ha producido un colapso de la sociedad de clases y su estructuración política en el Estado-Nación a través de la representación y confrontación de intereses plurales. La existencia de la masa presupone una desestructuración social y política de la que son índice el antisemitismo y el imperialismo. La pérdida de una estructura sistemática deja a los individuos abandonados a sí mismos. La masa se constituye por la combinación de ese aislamiento y la totalización de los individuos aislados. En ella son englobados individuos sin verdaderos contactos sociales y desarraigados. Por eso esta totalización del aislamiento tiene que ver "con la creciente funcionalización de nuestra sociedad, 0 , más bien, con el hecho de que el hombre moderno se ha convertido crecientemente en una mera función de la sociedad. El mundo totalitario y sus ideologías [...] reflejan el aspecto radical de funcionalización de los hombres" (Arendt, 2005a, 459).

La sociedad considerada como un todo funcional supone una diferenciación y una coordinación bajo criterios de eficacia y concertación en la que fines y medios se relacionan en términos de calculabilidad. Se trata de una funcionalización que manifiesta una tendencia a la indiferencia de todo lo singular e individual, a hacer superfluos a los individuos en aras de asegurar el funcionamiento del entramado funcional. La experiencia que hacen las masas modernas se corresponde pues con el intento totalitario de hacer superfluos a los hombres (Arendt, 1981, 678). Dicho intento es inseparable de la consideración $y$, en parte, del tratamiento de las poblaciones como material administrable y funcionalmente organizable. El genocidio administrativo encaja pues en la lógica instrumental que se emancipa de toda finalidad y termina convirtiendo el funcionamiento en finalidad de sí mismo. "Con la política de aniquilación la función del antisemitismo se reduce [para Arendt] a la elección de las víctimas. [...] Las víctimas de la dominación total que se alza sobre sociedad de masas de individuos radicalmente aislados le parecen a Arendt en última instancia intercambiables" (Schulze) Rensmann, 2003, 105).

Estas condiciones prestan al proyecto totalitario de dominación una eficacia inusitada. La clave de ese proyecto consiste para Arendt en intentar someter el conjunto de 
la realidad a la idea de una ley que rige la evolución de la naturaleza y la historia. El poder totalitario se interpreta a si mismo como ejecutor de esa ley inapelable a la que han de someterse, voluntariamente 0 no, todos los individuos, que ven así cómo es negada su capacidad de decisión y de responder ante sí mismos y ante los demás. El caudillo es el mediador infalible de dicha ley. Su omnipotencia para imponerla es al mismo tiempo la verificación de la ley, la prueba de su verdad. La propaganda no persigue tanto dar crédito a aquello que se proclama como movimiento inexorable, cuanto implicar al mayor número posible en su ejecución. Esta forma de entender la relación entre idea y realidad es incompatible una sociedad plural y activa. Toda espontaneidad es una amenaza y debe ser perseguida dentro y fuera, en los fieles y en los enemigos. La absoluta maleabilidad de la sociedad exige de ésta que posea un carácter amorfo, que quede reducida a puro material manejable por los que se erigen en sus constructores y hacedores. Toda la realidad social es sometida a comando, organización y control.

Esta forma de poder totalitario se ejercita y verifica en los campos de exterminio como "poder absoluto". Se trata de un poder que organiza el orden temporal y social de todos los procesos vitales de los prisioneros, impone una estructura social clasificatoria y cambiante que supone una distribución azarosa e imprevisible de posibilidades efimeras de supervivencia. Crea un sistema de colaboración que difumina la diferencia entre perpetrador y víctima, etc. Transforma el trabajo en un medio de aniquilación. Y todo ello emancipado de cualquier exigencia de legitimación o de normas establecidas de modo estable. Ser agredido, torturado o asesinado arbitraria y caprichosamente se convierte en una posibilidad omnipresente, de modo que la línea que separa la muerte y la vida desaparece. Pero como hemos visto, ese poder absoluto "no se da por satisfecho meramente con matar, ese punto último de referencia de todo poder. Antes transforma las estructuras universales de la relación humana con el mundo: el espacio y el tiempo, la relación social con los otros, la relación con las cosas en el trabajo, la relación de los seres humanos consigo mismos. Se sirve de algunos elementos y métodos de las formas tradicionales de poder, las combina y la potencia, se deshace de su instrumentalidad y se convierte asi en una forma de poder específica" (Sofsky, 1993, 29).

\section{AusCHWITZ: LÍMITE DEL PENSAR Y VUELCO DE LA CIVILIZACIÓN EN BARBARIE}

También Adorno vio en Auschwitz una cesura que obliga a los medios convencionales de análisis racional a cuestionarse a sí mismos y a cuestionar la marcha histórica en la que pudo abrirse un abismo tan insondable de dolor e injusticia. Pues no sólo la efectividad histórica de un sujeto divino suprahistórico, sino también la de la razón, la del sujeto burgués o la del proceso dialéctico quedaron en suspenso en los campos de exterminio del Tercer Reich. Una catástrofe de tales dimensiones, en la que se comenzó a eliminar sistemáticamente a una parte de la humanidad y se pudo hacer de dicha aniquilación un problema puramente técnico y organizativo, pone de manifiesto la gravedad del fracaso de las fuerzas y los poderes sobre los que se habian apoyado hasta ese momento las diferentes esperanzas históricas. Auschwitz representa pues una quiebra en el proceso civilizador que exige un replanteamiento radical en la forma de considerar dicho proceso.

Pero, ¿es posible dar explicación de esa quiebra? Como señala Adorno en la Dialéctica Negativa, "la aptitud para la metafísica quedó paralizada, porque lo que sucedió le hizo añicos al pensamiento metafísico especulativo la base de su compatibilidad con la experiencia" (Adorno, 1970b, 353). Sobre Auschwitz no es posible ni siquiera elaborar una filosofía de las situaciones límite, en las que todavía el existencialismo creía poder encontrar la fuente de la "autenticidad" humana (Adorno 1974c, 424; 1974a, 129; 1970a, 500ss). Si ya las reflexiones que pretenden dar sentido a la muerte, independientemente de cómo ésta tenga lugar, permanecen impotentes frente a su inconmensurabilidad para la "experiencia" humana, Auschwitz significa una imposibilidad de dichas reflexiones incomparablemente más radical, pues "desde Auschwitz, temer la muerte significa temer algo mucho peor que la muerte" (Adorno, 1970b, 364).

Es más, todo pensamiento teórico choca con barreras insuperables al intentar dar una explicación racional de Auschwitz. Con ayuda de la crítica de la economía política se pueden explicar y fundamentar las condiciones económicas, sociales y políticas de posibilidad de la toma del poder por los nacionalsocialistas y asimismo la "necesidad" desde el punto de vista de la política interna alemana de una guerra ofensiva. Con ayuda de un psicoanálisis flan- 
queado por una buena dosis de teoría crítica de la sociedad se puede explicar la capacidad de adaptación y sumisión de las masas, su frialdad e indiferencia frente al destino de las víctimas y su entusiasmo por un sistema que de hecho actuaba contra ellas y contra sus verdaderos intereses.

Sin embargo, la aniquilación de millones de seres humanos llevada a cabo de modo industrial en los campos de concentración y de exterminio está en contradicción con toda razón económica, aunque sea la "razón" de la cobertura con fuerza de trabajo "enemiga" de las necesidades de la industria bélica o la "razón" de la logística y la concentración de recursos en un momento en el que el ejército alemán se encontraba en una situación más que precaria en los diferentes frentes de batalla. La aniquilación de los judios no puede ser explicada de modo funcional a partir de dichas "racionalidades". Además, el intento de una explicación científica del universo irracional de los campos de exterminio conduciría a una racionalización inaceptable de los mismos (Claussen, 1988, 64).

En "Auschwitz" la realidad desborda toda capacidad de imaginación. La maquinaria de violencia altamente eficiente tenía como meta la nada, la eliminación incluso del recuerdo del objeto de la aniquilación hecho existir en cierta medida por definición del procedimiento aniquilador mismo. Así, lo irrepresentable se presenta a la desbordada capacidad imaginativa como realidad de la nada consumada. "El horror que por ahora ha culminado en Auschwitz produce la regresión del espíritu con una lógica que le es inmanente. Sobre Auschwitz no es posible escribir bien desde el punto de vista del lenguaje; es preciso renunciar a complejidades, si se quiere ser fiel a sus impulsos, y sin embargo con la renuncia se termina obedeciendo a la regresión universal" (Adorno, 1977c, 597-598). Ante lo inimaginable se abre un abismo de silencio, pues "sólo callando es posible expresar el nombre de la calamidad" (Adorno, 1974b), aunque ni siquiera "el silencio escapa al círculo" (1970b, 360). Por ello, "la conciencia que desea hacer frente a lo indecible se ve arrojada de nuevo al intento de comprender, si es que no quiere sucumbir subjetivamente a la locura que impera objetivamente" (Adorno, 1980, 116).

En el intento de comprender, Adorno se refiere a lo ocurrido en Auschwitz en términos muy parecidos a Arendt. Habla del "asesinato administrativo de millones de seres humanos inocentes" (Adorno, 1977d, 557). Y vincula ese asesinato administrativo de modo directo con la "frialdad", "principio fundamental de la subjetividad burguesa sin la que Auschwitz no habría sido posible" (Adorno, 1970b, 356). Sin ese principio los seres humanos no habrían aceptado un proceder semejante, se habrian rebelado. El problema es que ese principio estructura la sociedad y la vida individual, estableciendo la persecución del interés propio frente a los intereses ajenos por encima de cualquier otro criterio. $Y$ por paradójico que parezca, el instinto de rebaño observable por doquier no se opone a esa búsqueda del propio interés. El individualismo es el rasgo característico de la "masa solitaria", cuya constitución responde a la necesidad de agruparse de aquellos que experimentan la frialdad en sí mismos y en los otros y no pueden soportarla ni hacer nada para cambiarla. Justo esta incapacidad para identificarse con el otro "fue sin duda la condición psicológica más importante para que Auschwitz pudiera ocurrir en medio de seres humanos inofensivos y provistos en alguna medida de moralidad. [...]. La frialdad de la mónada social, del competidor aislado, se convirtió en cuanto indiferencia frente al destino de los otros en la condición para que sólo muy pocos se rebelasen" (Adorno, 1977b, 687).

El antisemitismo ofrece un código que permite explicar el mundo, que aparentemente permite conocer las causas de la opresión y personificarlas, pero además produce la ilusión de poseer el poder para eliminarlas gracias a la participación en la poderosa comunidad antisemita. Sin embargo, por medio de esta ideología las estructuras de opresión que sustentan las prácticas de dominio y exclusión son doblemente enmascaradas, para así mantener encadenados a los sujetos privados de su subjetividad y su individualidad. Las condiciones sociales del aislamiento, el sometimiento, la presión a adaptarse a lo existente y la renuncia, que abocan en última instancia a un debilitamiento de la conciencia independiente, no sólo afectan a los antisemitas, sino a todos los miembros de la sociedad. El origen de las disposiciones antisemitas se encuentra en la dialéctica de la socialización.

El mecanismo de la represión y la proyección paranoica no son simplemente mecanismos de la economía psíquica individual, sino mecanismos de la civilización. El orden totalitario no hace más que ponerlos a su servicio. Sin reflexión, el sujeto se hace incapaz para la diferencia y se convierte en un mecanismo de reacción primitivamente 
animal. El instinto destructor del fascismo no es más que el despliegue de esa incapacidad para la diferencia. Sólo la capacidad de dar un paso atrás, la capacidad de pensar en cuanto reflexión y autocorrección que percibe la necesaria aportación conceptual en cuanto tal e impide al mismo tiempo su absolutización, puede liberar al conocimiento de su sombra paranoica.

Como es bien conocido, el carácter autoritario es el tipo de carácter que permite a Adorno rastrear la conformidad y la complicidad con los poderes que organizaron y perpetraron el genocidio ${ }^{6}$. Su núcleo no es otro que la ambivalencia entre sometimiento y rebelión coagulada en el psiquismo de los que se aferran al orden existente. Dicho carácter les permite dar una salida al conflicto interior identificándose con el dominio encarnado en una figura personal y proyectando la agresión contra grupos identificados como más débiles. Partiendo del análisis freudiano, es posible explicar por qué el carácter autoritario tiene que dirigir la agresión contra grupos considerados extraños. Su debilidad le impide dirigirla contra las autoridades del propio grupo. El conflicto intrapsíquico se proyecta a la relación entre el propio grupo y los grupos declarados ajenos, lo que permite la descarga de la agresividad y la identificación con la autoridad. El resultado es una paradójica "rebelión conformista": una especie de combinación entre el placer de obedecer y la agresión contra los indefensos.

También encontramos la misma necesidad de identificación con la autoridad o con el colectivo en el "narcisismo herido", que no es simplemente una figura históricamente posterior al carácter autoritario. Su clave está en el conflicto entre la necesidad de una ocupación libidinal de la propia persona y el agravio permanente que las condiciones sociales infringen a los individuos para asegurar la autoconservación. Dichas condiciones son percibidas como ajenas, extrañas o destinales $y$, al mismo tiempo, como precarias, cuando no asociadas a insuficiencias de los propios sujetos amenazados, pero raramente identificadas como resultado de coacciones sistémicas. Si las exigencias de autoconservación reclaman una ocupación libidinal adicional de la propia persona (narcisismo), la incapacidad de controlar las condiciones de existencia provocan un agravio permanente que abre y reabre la herida narcisista: "El yo experimenta [...] su impotencia real como agravio narcisista" (Adorno, 1972b, 72). La solución a este conflicto se produce a través de la colectivización del yo gracias a la identificación compartida. El narcisismo dañado encuentra cumplimiento en el narcisismo colectivo (Adorno, 1972a, 419).

No es que Adorno espere de la psicología social una explicación de la catástrofe (Adorno, 1980, 186). Estas aportaciones resultan significativas sólo para descartar falsas explicaciones, sobre todo aquéllas que pretendan considerar el genocidio obra de una banda de criminales con rasgos demoniacos excepcionales. La movilización de conceptos como la "frialdad burguesa" o el "carácter autoritario" son mucho más intranquilizadoras, porque vinculan el genocidio con la patogénesis normalizada de subjetividades hiperadaptadas y conformes con una aniquilación masiva o al menos incapaces de resistirse. La desproporción de la catástrofe proviene de su carácter administrativo y frío, de una funcionalidad que había penetrado hasta el alma de ejecutores, cómplices y espectadores (Adorno, 1980, 117).

Supuestas estas condiciones sociales e individuales de posibilidad, lo que Adorno subraya de la eliminación industrial y burocráticamente organizada de innumerables víctimas es que esta forma de asesinato masivo supone un salto cualitativo que afecta al carácter mismo de la muerte, que ya no es lo único que les queda a los asesinados, por pobre que sea, sino algo de lo que también han sido expropiados. La muerte no es pues una invariante de la existencia humana que a todos iguala, como ingenuamente se dice. Las condiciones en que se produce pueden llegar a afectar a su misma esencia y de modo irreversible. En los campos de concentración y exterminio la experiencia de la muerte invade paradójicamente el ámbito mismo de lo viviente, la frontera entre la vida y la muerte sufre una transformación hasta ese momento desconocida:

"En los campos de concentración del fascismo se eliminó la línea de demarcación entre la vida y la muerte. Esos campos crearon un estado intermedio, esqueletos vivos y seres putrefactos, victimas a las que les falló el suicidio, la risa de Satanás sobre la esperanza de vencer a la muerte. Como en los epos invertidos de Kafka pereció allí aquello que da la medida a la experiencia: la vida vivida desde sí misma hasta su final" (Adorno, 1977a, 273).

La eliminación de todo resto, la conversión de las víctimas en humo, es el signo de que la vida de los aniquilados no tiene valor alguno, de que la vida individual es com- 
pletamente indiferente, superflua. Pero esta indiferencia de lo singular anida para Adorno en el propio principium idividuationis, en el triunfo de una individualidad juramentada con la ley universal de la ventaja individual, que bajo pretexto de asegurar al yo, lo sacrifica.

"Que en los campos ya no muriera el individuo, sino el ejemplar, tiene que afectar al morir también de aquellos que escaparon a la medida. El genocidio es la absoluta integración que se prepara por doquier donde los seres humanos son cortados por el mismo patrón, son disciplinados, como se decía en el ejército, hasta que, como desviaciones del concepto de su propia nulidad, eran literalmente eliminados. Auschwitz confirma el filosofema de la pura identidad en cuanto muerte" (Adorno, 1970b, 355).

¿Resulta legítima esta afirmación de Adorno? ¿Realmente es nuestro Brave New World, en caso de que el diagnóstico de A. Huxley sea certero, "un único campo de concentración, que, carente de alternativa, se tiene por el paraíso" (Adorno, 1977e, 99)? ¿Se pueden trasladar al pensamiento identificador y a los mecanismos de integración de la sociedad actual el carácter aniquilador que encontramos en la integración absoluta de los seres humanos y en la destrucción exterminadora de toda singularidad e individualidad de los campos de concentración? ¿No lleva a cabo Adorno una identificación inaceptable de categorías lógicas, por un lado, y sociales e históricas, por otro? Ciertamente Adorno percibe una conexión y, por así decirlo, una imbricación entre la identidad subjetiva, la lógica y la formal. En la base de todas ellas se encuentra el mismo proceso histórico y social constituido por el intercambio y la dominación de la naturaleza, se ejercita la dominación que en Auschwitz se vuelve total. Esto es lo que la protohistoria de la catástrofe ha de sacar a la luz.

\section{LA PROTOHISTORIA DE LA CATÁSTROFE}

A diferencia de aquellos que en el otoño de 1944, a la vista de un final previsible de la guerra, empiezan a pensar en la "reconstrucción", Adorno se niega a pensar en todo lo que sea reconstruir: "Resulta idiota pensar que después de esta guerra la vida podrá continuar 'normalmente' y aún más que la cultura podrá ser 'restaurada' - como si la restauración de la cultura no fuera ya su negación. [...] Mientras que la situación se prolongue, se perpetuará la catástrofe" (Adorno, 1980, 62). Adorno interpreta aquí, como puede verse, la perduración de las condiciones que hicieron posible la recaída en la barbarie como pervivencia de la catástrofe misma (Adorno, 1977b, 674). A primera vista sin embargo, esa identificación de la reconstrucción después de la guerra con la prolongación de la catástrofe parece presuponer una analogía inadmisible que amenaza con desmentir la tesis de que Auschwitz sea una "quiebra de la civilización", como no menos la tesis de su singularidad y su inconmensurabilidad con el resto de la historia, pues una identificación tal llevaría a constituir la catástrofe de Auschwitz en una especie de invariante histórica afectada sólo por diferencias de grado. Contra esto se opone el mismo Adorno decididamente (cfr. Adorno, 1980, 268).

Pero por otro lado, para él no es aceptable reducir los campos de exterminio sencillamente a "un incidente en la marcha triunfal de la civilización" (Adorno, 1980, 267). Singularidad equivaldría entonces a una delimitación no sólo temporal, sino también social y cultural del nacionalsocialismo, que convertiría a éste en una especie de avería circunstancial. Frente a esto afirma Adorno: "El hecho de que Auschwitz haya podido ocurrir en medio de toda una tradición de filosofía, arte y ciencias ilustradas no significa simplemente que ella, el espíritu, no llegara a prender en los hombres y a cambiarlos. Precisamente en esas ramas del espiritu, en la pretensión enfática de su autarquía, habita la mentira" (Adorno, 1970b, 359).

Así pues, hay que rechazar la afirmación de una pura invariabilidad, ya que esto supondría banalizar todas las catástrofes haciéndolas intercambiables, y además Ilevaría necesariamente a una resignación frente a lo inevitable, pues si siempre ha ocurrido lo mismo, resulta imposible pensar en una alternativa. Además, el concepto de invariabilidad infiere a las víctimas una nueva injusticia en su singularidad al eliminar las diferencias entre ellas. Pero por otra parte, la afirmación de la singularidad de Auschwitz no debe ir tan lejos, que éste quede reducido a un acontecimiento puramente contingente, pues esto conduce a un positivismo histórico para el que toda la historia no es otra cosa que el acontecer fáctico en su contingencia. Esto supondría una relativización minimizadora y reduciría considerablemente la relevancia de Auschwitz de cara a comprender la historia y la sociedad en cuyo seno pudo tener lugar dicha catástrofe (Claussen, 1987, 9s). Esa si- 
tuación paradójica lleva a Adorno a formular una frase que a primera vista parece contradictoria: "La identidad se encuentra en la no identidad, en lo aún no acontecido, que denuncia lo que ocurrió. [...] Quien se sustrae a la evidencia del crecimiento de lo espantoso no sólo se abandona a la contemplación carente de sensibilidad, sino que además pierde de vista, junto con la diferencia específica de lo más reciente respecto a lo acaecido anteriormente, la verdadera identidad del todo, del terror sin fin" (Adorno, 1980, 268).

Sólo la percepción de la singularidad cualitativa permite captar paradójicamente la identidad dentro del proceso que ha conducido a los horrores inimaginables de Auschwitz. Lo que hay que evitar es pues, por una parte, el hechizo de la filosofía del origen o philosophia prima, en la que toda la realidad se deduce más o menos directamente de un solo principio, en la que lo singular es la expresión o manifestación de la estructura ontológica básica de la realidad, y es igual que dicha estructura se determine positiva o negativamente. Pero, por otra parte, sería ilícito mantener una desconexión de los fenómenos, pues esto no hace justicia a las dimensiones y la persistencia de la negatividad histórica.

La identidad de la no identidad o viceversa, que el nuevo horror permite descubrir, podría caracterizarse de entrada con K. Marx como la estática de la dinámica social. Dado que la sociedad avanza de modo antagónico y pseudonatural, la dinámica de su expansión desenfrenada sigue siendo una reproducción del viejo antagonismo y por tanto estática. La irracionalidad de las crisis cíclicas, la impotencia de los sujetos socializados frente a la marcha de su propia historia, asi como el sufrimiento evitable pero persistente, ponen de manifiesto que "la dialéctica histórica conduce en cierto sentido a una constancia de la fatalidad" (Adorno, 1972c, 234).

El concepto marxiano de "prehistoria", al que Adorno quiere mantenerse fiel con su idea de "historia natural", comprende el proceso histórico bajo el signo de la persistente falta de libertad. No se trata pues de una continuidad positiva, sino la continuidad de la historia de sufrimiento. Cuando Marx califica el trabajo asalariado "libre" como "esclavitud asalariada", lo que pretende es romper la apariencia de un progreso que ciega frente a la continuidad de la coacción más allá de sus mutaciones históricas. Lo decisivo, la eli- minación de la coacción social que produce el sufrimiento, está todavía por realizar (Schmid, 1990, 32) ${ }^{7}$. Por ello, para Adorno no basta con limitarse a desenmascarar la historia humana como prehistoria, como estática en y a través de la dinámica, sino que hay que sacar a la luz el reverso oculto de la misma.

No se trata de considerar la dominación como fundamento ontológico y negativo de la historia, sino de impedir una relativización del sufrimiento en ella. De un modo negativo se puede reconocer la unidad de los momentos discontinuos y caóticamente dispersos de la historia en cuanto continuidad de la dominación destructora, dado que el sufrimiento injusto no ha sido todavía eliminado en ninguno de ellos. La figura más reciente de iniquidad abre los ojos para el sufrimiento actual en cada momento, así como la persistencia del sufrimiento injusto es la prueba de la perduración del dominio destructor. Adorno no pretende formular con esta construcción de la historia en cuanto "historia natural" una nueva metafísica de la historia, ahora negativa, sino que pretende forzar un cambio de perspectiva en la consideración de la misma.

W. Benjamin lo ha formulado de un modo insuperable al referirse a la dictadura nacionalsocialista frente a aquellos que se sorprendian de que ocurrieran cosas semejantes en el siglo veinte: "La tradición de los oprimidos nos enseña que la regla es el 'estado de excepción' en el que vivimos" (Benjamin 1972, 697). La posibilidad de pensar conjuntamente "regla" y "excepción" o -con Adorno- "continuidad" y "discontinuidad", "identidad" y "no identidad" depende de ese cambio de perspectiva. No se pretende ontologizar la discontinuidad, el estado de excepción o el sufrimiento, como si se tratara de una determinación esencial de la historia, de la que lógicamente no habría posibilidad de liberarse. Más bien lo que se exige aqui es adoptar la perspectiva de los oprimidos, de las víctimas de la historia, y no simplemente por solidaridad con ellas, sino en honor a la verdad de esa historia. Adorno comparte con Benjamin la convicción de que es necesario un cambio de perspectiva, como revela su interpretación de Kafka: "En la Edad Media, tortura y muerte se aplicaban 'invertidas' a los judíos; en un célebre pasaje de Tácito ya se acusa a su religión de religión invertida. Los delincuentes fueron colgados cabeza abajo. Tal como la superficie de la tierra tiene que haberse presentado a esas víctimas en las infinitas horas de su agonía, así es como la fotografía el agrimensor Kafka" (Adorno, 1977a, 284). 
Para las víctimas de la historia -con sus sufrimientos individuales e inintercambiables- todo progreso es nulo: "El sacrificio más reciente es siempre el de ayer" (Adorno, 1977a, 269). Cada víctima es como el negativo de la coacción persistente y por tanto la negación de que haya existido realmente progreso. Lo contrario sería integrar y superar hegelianamente las víctimas en el movimiento del todo hacia un final feliz, degradándolas a estaciones de la ascensión imparable del espíritu o del género humano, y convertir de ese modo sus sufrimientos en una "quantité négliegeable" que inevitablemente hay que pagar como precio de ese ascenso. Esto podrá contribuir a la justificación de la (falsa) totalidad, pero desde luego no a hacer justicia a las víctimas, pues desde su perspectiva toda víctima es una víctima de más. Para el que es aniquilado, la negatividad aniquiladora no puede ser relativizada, no puede ser reducida a momento, a aspecto. Para él la negatividad es total, porque la aniquilación es total.

La única forma de no hacer desaparecer en una interpretación de la historia universal el sufrimiento, que en Auschwitz alcanzó cimas insospechadas, o de no reducirlo a mera contingencia vinculada a contextos plurales y por ello mismo relativos, es contemplar desde él la totalidad de la historia. Lo más singular -Auschwitz- obliga a cambiar el punto de vista sobre el todo, de modo que desde él se abra al que lo contempla la noche oscura de la historia: "es innegable que los martirios y humillaciones nunca antes experimentados de los que fueron deportados en vagones para el ganado arroja una intensa y mortal luz hasta sobre el más lejano pasado" (Adorno, 1980, 266). De este modo, "la historia manifiesta y conocida aparece en su relación con aquel lado oscuro, que ha sido pasado por alto tanto por la leyenda de los Estados nacionales como por su crítica progresista" (Horkheimer/Adorno, 1981, 265).

Para Adorno, Auschwitz ha rasgado definitivamente el velo de optimismo que ocultaba las contradicciones del proceso emancipador moderno. Las promesas de autonomía y de justicia que la llustración hizo a la humanidad no se han visto frustradas por el asalto de fuerzas atávicas o por las resistencias recalcitrantes de poderes pretéritos. Aceptar una explicación así no haría sino aumentar la indefensión frente a la barbarie presente. Auschwitz obliga a enfrentarse con la dialéctica de la llustración, con la imbricación de progreso y regresión, con la complicidad de la razón moderna con el principio de dominación. Esta obligación tiene su origen en la convicción de que es necesario dar cumplimiento a dichas promesas, pero también de que la mayor catástrofe del siglo XX europeo revela una constitución patológica de la sociedad y los individuos de tal profundidad, que exige una crítica radical de la racionalidad que subyace a ella. Es necesario replantear de raíz las relaciones de los individuos con su propia naturaleza interna, sus relaciones con la naturaleza externa que pretenden dominar y las relaciones que mantienen entre sí.

En este horizonte es en el que Adorno y Horkheimer elaboran su protohistoria de la modernidad catastrófica con el fin de rastrear las condiciones de posibilidad de semejante fracaso de las expectativas de emancipación albergadas por la llustración, es decir, "por qué la humanidad, en vez de alcanzar un estado verdaderamente humano, se hunde en una nueva forma de barbarie" (Horkheimer/Adorno, 1981, 11). La argumentación de la Dialéctica de la llustración gira en torno a la relación entre tres aspectos o dimensiones de la dominación, que para sus autores se encuentran en estrecha relación y determinación mutua: la dominación de la naturaleza, la dominación social y la dominación en el sujeto. Adorno considera que el principio de identidad es inherente tanto a la racionalidad identificadora y dominadora de la naturaleza como a la racionalidad del intercambio capitalista. Además, sin la rígida identidad del sujeto duramente conquistada contra la naturaleza externa e interna y que sirve de modelo a la identidad de lo difuso y múltiple bajo la unidad sintética del objeto, no hubiera sido posible dominar la naturaleza.

Adorno pensaba que es necesario replantear de raíz las relaciones de los individuos con su propia naturaleza interna, sus relaciones con la naturaleza externa que pretenden dominar y las relaciones que mantienen entre sí. Estas relaciones han estado presididas por el principio de identidad que somete coactivamente lo diferente, singular y múltiple, que ejerce violencia sobre su otro, lo no idéntico. La identidad prepotente del yo contra la multiplicidad de impulsos instintivos, la equivalencia igualadora del principio de intercambio capitalista, la imposición conceptual que hace disponible la naturaleza para su dominación, todas estas formas de identidad deben someterse a una reflexión crítica que permita llevar a cabo una rememoración de la naturaleza en el sujeto, condición de posibilidad de una reconciliación en la que lo diferente conviva sin temor.

ARBOR CLXXXVI 742 marzo-abril [2010] 245-263 ISSN: 0210-1963

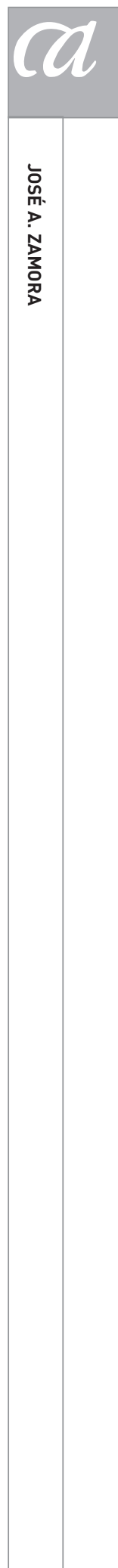

255 


\section{H. Arendt y Th. W. Adorno: PUNTOS DE ENCUENTRO Y DIVERGENCIAS}

Hemos visto como Adorno y Arendt elaboran las líneas maestras de su pensamiento en confrontación con la catástrofe de Auschwitz y también que existen formulaciones muy próximas, cuando no coincidentes, para identificar los rasgos esenciales de la misma y señalar ciertas claves para intentar comprenderla. Arendt y Adorno vuelcan todos sus esfuerzos en sacar a la luz la complicidad de la modernidad con el horror. Sin embargo, resulta imposible pasar por alto las diferencias sustanciales de sus planteamientos teóricos. La crítica adorniana de la sociedad moderna capitalista se inscribe en la tradición dialéctica y materialista, mientras que la crítica arendtiana se apoya en un existencialismo orientado políticamente y en un republicanismo libertario. Analicemos pues estas diferencias.

En el esfuerzo por comprender la catástrofe de Auschwitz se ha querido señalar como una diferencia importante entre Arendt y Adorno la presencia o no de un esquema teleológico en el que los campos de exterminio y la dominación total aparecen como telos de la historia. Mientras que Arendt habría aportado "elementos" con los que empezar un "proceso interminable por el que el totalitarismo podría ser comprendido", Adorno habría presentado la catástrofe como "resultado cuasi necesario de la evolución de la cultura y de la racionalización de la sociedad" (Villa, 2007, 4). Pero esta supuesta diferencia es más que cuestionable. Ciertamente es importante que no se identifique en Arendt "orígenes" con "causas" (Birulés, 2006, 43). Si buscamos nexos entre Auschwitz y el desarrollo tecnológico y su aplicación en el terror genocida, la universalización de la organización burocrática de la vida social, el sesgo autoritario de los Estados nación, el darvinismo social como ideología popular, la sustracción de los procesos administrativos y la acción de los sujetos implicados en su funcionamiento a la determinación moral, etc. en la época moderna (Bauman,1997), se puede caer en una especie de fatalización de la historia que convertiría todo intento de crítica en una empresa absurda. Pero eso mismo ya lo advirtieron Th. W. Adorno y M. Horkheimer: "Ciertamente, desde el punto de vista retrospectivo, todo parece haber sucedido tal y como tenía que ocurrir y no de otra manera. [...] pero al repetir otra vez en el concepto la fatalidad del acontecimiento, uno se la apropia en cierto sentido" (Horkheiner/Adorno, 1996, 650).
Quien lee la Dialéctica de la llustración como una Fenomenología del Espíritu invertida, la lee mal. El concepto de protohistoria de la modernidad catastrófica, como hemos mostrado en otro lugar (Zamora, 2004, 125ss), tiene una significación teórica diferente a la que se le suele atribuir. Es lo contrario de una filosofía del origen, en el que supuestamente está incoado todo el proceso y su resultado. Su tesis de que el mito ya es ilustración y la ilustración da un vuelco en mitología, lo que hace es romper con el esquema teleológico de despliegue y desarrollo, como hemos explicado más arriba. La Dialéctica de la llustración trata pues de la constitución histórico-natural tanto de la sociedad capitalista moderna como de la subjetividad instrumental desde la perspectiva de la situación social y cultural que se manifiesta en la industria de la cultura, el antisemitismo y el genocidio judío, y ciertamente como una constitución malograda. Con ello se quiere sacar a la luz el reverso de la "lógica de las cosas" ilusoriamente transfigurada por la ideología del progreso. De lo que trata es pues de la dialéctica entre la constitución del yo y su negación, entre el dominio de la naturaleza y su destrucción, entre el progreso y la regresión, entre la universalidad del intercambio y la liquidación del individuo. Relación dialéctica no significa que el primer término esté unido al segundo por una relación causal. El diagnóstico de un fracaso fáctico de la llustración tampoco debe confundirse con la tesis de un resultado inexorable.

Por eso resulta claramente insuficiente la caracterización de las diferencias entre Adorno y Arendt atribuyendo al primero una "abstrusa Geistesgeschichte hegeliana" y a la segunda una "'ciencia política' histórica concreta" (Villa, $2007,44)^{8}$. La misma autora de esta atribución tan desigual reconoce una presencia indirecta de la figura de Hegel y de su Filosofía del Derecho en la importancia que Arendt atribuye a la relación entre sociedad civil y Estado en los orígenes del totalitarismo. No en vano es en Hegel donde encontramos por primera vez una diferenciación sistemática del Estado político y la sociedad burguesa. Mientras esta última es concebida como un sistema de "dependencia económica universal", el Estado, en tanto que en él la razón sólo parcialmente realizada en la sociedad burguesa se encuentra a sí misma, aparece como una figura autónoma y desarrollada de la moralidad.

En su ensayo sobre el imperialismo de 1948, Arendt define el Estado nacional como "el baluarte hasta ahora más 
fuerte contra el dominio ilimitado de la sociedad burguesa, contra la toma del poder por la chusma..." (Arendt, 2004, 32). Ya hemos visto que Arendt interpreta el imperialismo como el secuestro del Estado por la burguesía y su sometimiento a la lógica económica de la expansión por la expansión. La traducción política de la lógica del capitalismo es atribuida a un afán desmedido de la burguesía por hacer valer sus intereses, un afán que culmina dentro del ámbito político del Estado con el triunfo de la idea de una expansión ilimitada del poder. Al final de esta evolución se encuentra la dominación total. Así pues, la dominación política adquiere rasgos totales a través de su vinculación con la lógica expansiva del capital para separarse posteriormente de ella y convertirse en un fin en sí mismo que se sirve entonces de otras alianzas con el nacionalismo populista y racista. En este sentido, para Arendt, el "totalitarismo es un fenómeno de la modernidad, pero no tanto del Estado moderno cuanto de la sociedad moderna" (Brunkhorst, 1999, 53s).

Sin embargo, ¿cómo se pasa de un supuesto ascenso político de la burguesía y su deriva imperialista a la alianza entre capital, élite y populacho que permite el salto históricamente contingente del imperialismo al totalitarismo? Según parece, por el agotamiento de las fuentes de solidaridad aglutinadas por los Estados nacionales, y esto por culpa de la dinámica expansiva de la "sociedad burguesa" o de la "sociedad económica moderna". La expansión por la expansión sería el principio organizativo de la sociedad moderna, no del Estado moderno. Sin embargo, Arendt no mantiene siempre esta contraposición. En otros momentos la argumentación parece basarse en una contraposición entre Estado y Nación, que prepara el asalto al Estado por el populacho cargado de sentimientos nacionalistas y racistas, (inevitable) degeneración del pueblo incoada en su configuración como nación. Pero en realidad, tanto la primera contraposición arendtiana entre Estado y sociedad burguesa resulta problemática, sobre todo si tenemos en cuenta que resulta imposible imaginarse una acumulación capitalista sin la colaboración del Estado, como la segunda resulta confusa, pues no sólo los límites, sino sobre todo las transiciones entre pueblo, sociedad burguesa y populacho carecen de explicación convincente. Lo que Arendt parece defender es la existencia de una cesura entre, por un lado, un poder sujetado estatalmente y una acumulación capitalista dentro de ese marco, que por tanto reconocen (y se sirven de) los límites basados en una solidaridad nacional o de un pueblo, y, por otro lado, un capital y un poder desbocados, que primero supeditan el marco estatonacional a su lógica expansiva, para posteriormente destruirlo bajo el asalto de los movimientos populistas/nacionalistas (völkisch). El marco del Estado moderno permitiría, según Arendt, la existencia de una esfera pública de libertad política de los ciudadanos basada en la soberanía popular y los derechos humanos, pero la pérdida o transformación totalitaria de ese marco supone la disolución de dicha esfera y su escisión en élites totalitarias y populacho propia de la sociedad de masas. Como ha visto claramente Brunkhorst, Arendt identifica de manera no siempre clara los términos de dos contraposiciones conceptuales: la de pueblo soberano y populacho, por un lado, y la hegeliana de Estado y sociedad, por otro. "El populacho pertenece a la esfera social y el pueblo a la estatal" (Brunkhorst, 1999, 87).

Mientras que el análisis arendtiano del imperialismo dirige su mirada crítica a la burguesía y recoge en cierta medida la constitución antagónica de la sociedad, en la crítica del populacho resuenan todos tonos del pesimismo cultural conservador sobre la sociedad de masas. La contraposición entre pueblo y populacho apunta a una identificación elitista del pueblo con una élite políticamente activa que personifica el concepto de Estado moderno, pero ya sin referencias al antagonismo social reducido a una cuestión sin significado político al que se puede responder con medidas administrativas. Esto conduce en última instancia a un vaciamiento social de lo político y viceversa. Arendt no concede prácticamente ninguna significación al análisis económico y sociológico del capitalismo.

Esta conclusión resulta tanto más significativa, cuanto que Arendt va reorientando progresivamente su atención desde la lógica acumulativa del capital hacia la crítica de la sociedad laboral de masas y las formas de acción y de racionalidad instrumentales que le sirven de fundamento. Los individuos atomizados y desprovistos de mundo, privatizados, son resultado de la glorificación moderna del trabajo (Arendt, 2005b, 315ss) que reduce la existencia a mera reproducción de la vida. La existencia compartida (Mitsein) ha quedado rota por el triunfo del homo faber y del animal laborans y con ellos de unas formas de vida que producen alienación frente al mundo y en las que está inscrita la reducción de todo lo dado a puro material de fabricación, así como la tendencia a eliminar la contingen- 
cia y la libertad. La moderna sociedad productivista eleva la vida de la especie y su reproducción a absoluto único e inicia la conversión de los seres humanos en elementos atomizados de esa especie, átomos ciegos y meros soportes de funciones. Esa es la razón de una alienación generalizada y una atomización incompatibles con el sostenimiento del espacio público y de la comunidad política.

En consonancia con este planteamiento, su condena de la clase burguesa no se basa en una crítica sistemática del capitalismo. Más bien presenta afinidades reconocibles con la crítica conservadora y romántica de la sociedad de masas. Lo relevante en dicha clase son las tendencias que cristalizan en el pequeño burgués conformista y necesitado de seguridad, temeroso ante los cambios e hiperadaptado a las normas sociales, intelectualmente inflexible e interesado por sus beneficios, es decir, lo relevante es un carácter moral que tiene su lugar natural en la sociedad de masas y que resulta reconocible tanto en los instigadores como en los colaboradores del genocidio (Marti, 1997).

Llegados a este punto, intentaré mostrar que la matriz del pensamiento adorniano, pese a la coincidencia con ciertas formulaciones de $\mathrm{H}$. Arendt, posee otros vínculos genealógicos y otro alcance. Para ello empezaré por referirme a la crítica temprana de Marx a la Filosofía del Derecho de Hegel. Su teoría del Estado es tematizada en ella como una teorización cosificadora. Marx constata la existencia de una situación que no es explicable a partir de la voluntad de los individuos, cuya acción es interpretada más bien como realización de esa situación dada de antemano e inconsciente. Los individuos actúan en esa constelación social necesariamente como "funcionarios" de una estructura impuesta. La libre voluntad no es el objetivo de la socialización, sino mero accidente. En esta temprana confrontación con la Filosofía del Derecho Marx defiende que el Estado democrático sólo puede existir si supera la sociedad burguesa constituida por la asimetría de la propiedad privada. De aquí se deriva la necesidad de desarrollar la objetividad de las relaciones estatales y sociales desde la acción de los individuos, pero en el sentido de un desarrollo genético de la autonomización inconsciente de dicha objetividad que se les impone. La estructura de la sociedad se identifica pues con el dualismo de sociedad burguesa y Estado, pero es el proceso de dicha separación el que produce los elementos de la vida burguesa en cuanto tal. A su vez la separación de la sociedad burguesa y el
Estado debe ser concebida bajo la determinación formal de la constitución capitalista de la sociedad y su dinámica presidida por el antagonismo y la dominación.

Evidentemente dicha determinación formal no es perceptible desde el punto de vista de la acción y el pensamiento de los individuos, para los que sólo existen intereses, dinero, objetos, propiedades, derechos, etc. Las teorías burguesas reduplican ese punto de vista en sus sistemas conceptuales, se dejan engañar por la "apariencia de la circulación". Como no pueden pensar la acción individual como estructurada socialmente y la colocan como algo constitutivo y primero, la apariencia de la inmediatez es identificada como lo que realmente es. Por el contrario, según Marx, para comprender la estructura social o la determinación formal de la acción individual es preciso comprender el modo de producción capitalista en su conjunto: la relación entre trabajo concreto y trabajo abstracto, la producción de plusvalia y su acumulación, el antagonismo social y la lucha de clases. Es aquí donde encontramos la clave de la autonomización del valor acumulado frente a sus productores, por la que los individuos pierden su autonomía frente a un proceso anónimo de acumulación. Pero es muy importante, llegado a este punto, tener en cuenta que esta crítica de la objetividad autonomizada se dirige igualmente a las relaciones políticas (Estado) como a las sociales. En todo caso, Marx no va considerar el Estado como ámbito de realización de la moralidad y la sociedad burguesa como ámbito de confrontación de intereses.

Inscrita en esta tradición de pensamiento, la Teoria Crítica trata de conocer lo que se presenta bajo la figura del ser como apariencia necesaria que expresa la relación social autonomizada frente a los individuos en el capital. Bajo las condiciones transformadas en los años treinta, esta empresa exigía a los ojos de Horkheimer superar el dualismo simplificador de base y superestructura y preguntarse por la conexión entre la vida económica, el desarrollo psíquico de los individuos y las transformaciones en los ámbitos de la cultura en sentido estricto. De esta manera se pretendía responder a la progresiva subsunción de los ámbitos de vida cultural bajo las lógicas sistémicas de las estructuras capitalistas y estatales de organización. Al mismo tiempo se trataba de analizar la tendencia que mostraba el sistema hacia un modo postliberal de acumulación monopolístico. Como es conocido, existían dos posiciones encontradas en el Instituto de Investigación Social, la de F. Pollock y la F. L. 
Neumann, que sin embargo coincidian en la constatación de una evolución del capitalismo hacia la monopolización, pero disentían sobre la cuestión de si esta tendencia había producido un vuelco hacia un capitalismo de Estado en el que la función reguladora del mercado estaba siendo sustituida por la intervención y regulación directas de la economía por parte del poder político, lo que podía suponer una estabilización del sistema económico, pese a sus contradicciones, de consecuencias terribles, como el nacionalsocialismo ponía ante los ojos.

Neumann afirmaba frente a Pollock que el incremento de la función de la política que se manifestaba en el fascismo y que se prolongó en las democracias posfascistas era un producto del desarrollo del mismo capitalismo monopolista, es decir, de su tendencia a servirse de la burocracia estatal para realizar una planificación de la economía?. Es probable que Horkheimer y Adorno al decantarse por la teoría de F. Pollock sobre el capitalismo de Estado no fueran capaces de captar hasta qué punto la formación de monopolios sigue estando sujeta a la ley de la acumulación y lejos de eliminar la competitividad y el mercado, resultan ser su reverso dialéctico. Sin embargo, en los trabajos de Adorno a partir de mitad de los años cuarenta encontramos una teoría del "mundo administrado" que, a diferencia de la interpretación habitual, conecta con el programa de la Teoría Crítica en los años treinta y lo actualiza. Como señala Wiggershaus, "Adorno hablaba de la sociedad del intercambio (Tauschgesellschaft) de modo tan enfático como del mundo administrado, del dominio omnímodo del principio de intercambio como del dominio omnímodo de la organización y la administración" (Wiggershaus, 1987, $66)^{10}$. Con ello señala la complementariedad y reforzamiento mutuo de administración y explotación económica.

El objeto de la teoría de la sociedad adorniana es la objetividad social caracterizada como autonomización en la que son reconocibles tendencias estructurales que condicionan y son a su vez condicionadas por formas de conciencia, acciones, normas, motivaciones, relaciones y conflictos sociales, procesos psicodinámicos, etc. Para Adorno, en la sociedad moderna actúa un principio dinámico que hace depender la reproducción del sistema capitalista de la permanente expansión, también la reproducción de las instituciones políticas. Dicha expansión debe entenderse como una ampliación de la cosificación (principio de intercambio) y de la burocracia (mundo ad- ministrado) que posee carácter totalizador. Sin embargo, las relaciones sociales autonomizadas sólo se reproducen en y a través de la acción de los individuos, por lo que Adorno no concibe la sociedad como substancia, sino como mediación. Esto tiene una importancia para distinguir el discurso crítico sobre el aislamiento y la alienación en la formación de la masa respecto al discurso conservador ${ }^{11}$.

"El individuo aislado, el sujeto puro de la autoconservación, personifica en la absoluta oposición a la sociedad su más intimo principio. Aquello de lo que se compone, lo que colisiona en él, sus 'propiedades', son sin duda al mismo tiempo elementos de la totalidad social. El individuo es mónada en el sentido estricto de que presenta la totalidad con sus contradicciones, sin por ello ser alguna vez consciente de ella. Pero en la figura de sus contradicciones no siempre y permanentemente comulga con la totalidad, dicha figura no procede de modo directo de su experiencia" (Adorno, 1972b, 55).

Tenemos pues dos elementos cuyo efecto destructor reside en su vinculación: la integración de los individuos en una estructura funcional antagonista y la coacción a la permanente expansión económica. Intercambio y racionalidad instrumental resultan ser elementos constitutivos de una estructura social que se autonomiza frente a los individuos y se constituye en totalidad antagónica, es decir, de una dinámica expansiva de la imposición de los mecanismos económicos estructurales. Por el contrario, lo que estructura el mundo bajo los imperativos productivistas en Arendt son máximas de acción que los individuos se dan a sí mismos. Adorno está muy lejos de pensar que los potenciales totalitarios de la sociedad moderna nacen de una autosumisión a la ideología del trabajo como fin en sí y a sus imperativos formales. Esto no debería ser olvidado cuando se constata la proximidad de Arendt y Adorno en denuncia de la pérdida de la experiencia, la eliminación de la espontaneidad, el despliegue de la frialdad burguesa, la anulación de la capacidad de pensamiento y juicio, etc. en relación con las condiciones que hicieron posible la dominación total de lo universal sobre lo singular, que hicieron posible Auschwitz. Para Adorno, la destrucción de las posibilidades de individualidad, libertad y emancipación es inherente a la tendencia que preside los principios estructurales del orden burgués y que presentan afinidades intimas con el antisemitismo. 
1 Estas experiencias fueron determinantes para la forma en que Adorno y Arendt entendieron su identidad y su tarea como intelectuales. El exilio puede entenderse como una descripción metafórica del lugar político y epistemológico que posibilita el pensamiento y el juicio críticos (Auer, 2003, 54), por más que la experiencia de ambos en EEUU resulte bastante diferente (Vecchiarelli, 2003).

2 De todos estos episodios encontramos referencias en la correspondencia de $\mathrm{H}$. Arendt con Heinrich Blücher, carta del 2-8-1941 (Arendt/ Blücher, 1996, 127), y con Karl Jaspers, cartas del 4-7-1966 y 18-41966 (Arendt/Jaspers, 1993, 679 y 670). No cabe duda que el rigor con que Arendt juzga a Adorno contrasta con el tono en que juzga y a veces minimiza la implicación de Heidegger en el periodo nacional-socialista. Arendt se mantuvo fiel hasta 1975 a quien había llamado "cobarde" e incluso "delincuente", pero al que siguió considerando su maestro, un "filósofo genial" y su amante marburgés (Arendt/Heidegger, 1998; Grunenberg, 2006). En la Laudatio por su ochenta cumpleaños en 1969 se refiere al autor de Ser y tiempo como un "rebelde" a quien siempre le importó "la cosa misma (también la pasión) del pensamiento", al que volvió a insuflarle vida. Que "hace 35 años... cediese por una vez durante 10 meses a una tentación", es minimizado como una "déformation professionelle", "pues la inclinación hacia lo tiránico se puede documentar teóricamente en todos los grandes pensadores (Kant es la gran excepción)" (Arendt, 1969, 902). Para

Recibido: 11 de noviembre de 2008 Aceptado: 15 de febrero de 2009
Heidegger va más allá de lo personal, pues su critica de la sociedad es en gran medida una variante de la crítica heideggeriana de "se" (Man) en Ser y tiempo (Brumlik, 2006, 1484).

3 Arendt se había referido ya muy temprano a los campos de exterminio como "fábricas de muerte" (H. Arendt: "La imagen del infierno" (1946), en A. Arendt, 2005a, 246).

4 "A partir de la década de 1950, cuando ella empezó a pensar en Auschwitz, esta teórica política identificó el mal radical, como hemos visto, con lo que más tarde llamó banalidad del mal, porque, tanto si se manifiesta en un sistema totalitario o en un Eichmann, el mal radical siempre implica la destrucción del pensamiento (que es una destrucción encubierta, generalizada, imperceptible $y$, por tanto, banal, aunque también sea escandalosa), que prefigura el escándalo de la aniquilación de la vida. Es evidente, entonces, que uno tendria que estar actuando de mala fe o carecer completamente de familiaridad con los textos más tempranos de Arendt para afirmar que ella exoneró o trivializó los crimenes de Eichmann de alguna manera" (Kristeva, 2001, 144). En el mismo sentido rastrea J. Marrades ciertas afinidades entre el concepto de "banalidad del mal" en Arendt y del "mal radical" en Kant (cf. J. Marrades, 2002).

5 En nuestro intento de relacionar el pensamiento de Arendt y Adorno sobre Auschwitz tiene escasa relevancia la controvertida equiparación de nazismo y estalinismo, cuya pertinencia ha sido sobradamente cuestionada. Lo que importa es la pertinencia de los argumentos referidos a Auschwitz, sean o no trasladables a los horrores del estalinismo. Esto no significa que ignoremos que la teoría del totali- 
tarismo pone su atención principalmente en las analogias estructurales desde el punto de vista del ejercicio de la dominación entre el bolchevismo/estalinismo, por un lado, y el fascismo/nacionalsocialismo, por otro. Para este fin la sociedad totalitaria es definida como una formación sui géneris, caracterizada por una ideología oficial, un único partido de masas, un monopolio de las armas, un control de los medios de comunicación y un sistema de control policial terrorista. El contraste se establece con los componentes estructurales de la sociedad democrática y liberal, frente a los que ambos suponen una quiebra, una suspensión de sus elementos constitutivos. El concepto de "totalitarismo" reúne en sí una componente historiográfica y científico-social y otra políticocosmovisional. Los rasgos que se atribuyen a las sociedades totalitarias son en realidad una mezcla de ambas componentes que presupone una construcción ideal de las democracias liberales cargada de carácter normativo. Dicha construcción funciona como presupuesto no reflejo que permite la abstracción bajo la que comunismo y nacionalsocialismo resultan comparables de cara a establecer rasgos estructurales comunes en los métodos y en la praxis de la dominación social. Esto no sólo resta relevancia a los diferentes contenidos ideológicos que sustentan el ejercicio de la dominación, sino que impide diferenciar entre el totalitarismo como fin o como medio. La principal función de la teoria del totalitarismo consiste en identificar a sistemas políticos que se convirtieron en una amenaza para otras formas de dominación de corte liberal y sirve a la autoidentificación positiva de los estados constitucionales liberales. Su problema fundamental consiste en sustraer a la reflexión crítica el ideal normativo que da fundamento a la teoria. Para una aproximación a los debates en torno al concepto de totalitarismo y específicamente de la aportación de Arendt, consultar Forti, 2008; Ganzfried/Hefti (eds.), 1997; Friedrich, 1957 y Schlangen, 1976.

6 M. Zuckermann se ha señalado los vínculos implícitos entre el concepto de la "banalidad del mal" (Arendt) y el "carácter autoritario" (Adorno). Cfr. Zuckermann, 2007, 678ss.

7 En el concepto marxiano de "prehistoria" se expresa el triunfo de la naturaleza sobre los seres humanos justo a través de la dominación técnica de la naturaleza misma (cfr. Schmidt, 1978, 37). El carácter cuasi natural del sistema capitalista, con sus crisis cíclicas y su impermeabilidad a la decisión libre de los sujetos que componen la sociedad, manifiesta el sometimiento de la sociedad burguesa a la naturaleza que ella dice dominar (cfr. Schmidt, 1987, 9ss.).

8 Sheila Benhabib ve las cosas de otra manera cuando afirma en un artículo publicado para celebrar el centenario del nacimiento de $\mathrm{H}$. Arendt: "El estudio 'Elementos y Orígenes de la dominación total' frustró ya a los contemporáneos de Arendt porque era una mezcla de historiografía, filosofía, periodismo e incluso contemplación literaria... Los historiadores han cuestionado (su) concepción de la burocracia bajo regímenes totalitarios; han refutado sus tesis sobre la desaparición moderna de la comunidad y el sentimiento creciente de abandono en el 'hombre-masa' en el época anterior al ascenso de Hitler al poder" (Benhabib, 2006).

9 Cfr. los textos más importantes de esta discusión en M. Horkheimer et all, 1981.

10 En otro lugar he analizado más a fondo la relación entre estas dos afirmaciones en la teoria adorniana de la dominación social de lo que puedo hacer en estas páginas (cf. Zamora, 2007, 30ss).

11 En su "Carta abierta a Hochhuth", Adorno se distancia claramente de dicho discurso: "Lo que hoy en día llaman masificación -yo mismo nunca he empleado esa palabra más que como crítico de su uso- se lo infligen a las masas esas pulcras camarillas e individuos que las administran y luego las increpan por ser masas" (Adorno, 1974d, 597). Cfr. también el fragmento "Sociedad de masas" en Horkheimer/Adorno, 1981, 270s. El concepto de sociedad de masas no explica la realidad que intenta nombrar, en todo caso señala, como dice Adorno, un punto oscuro sobre el que debe elevarse el conocimiento (Adorno, 1972d, 93). La crítica del nivelamiento que supuestamente produce la llamada sociedad de masas es en realidad un afirmación implícita del aristocratismo que da sentido a la crítica: "La nivelación de la sociedad de masas lamentada por los cómplices en la sociología y en el conservadurismo cultural no es en verdad otra cosa que la confirmación desesperada de la diferencia en cuanto identidad que intentan realizar las masas, completamente atrapadas por el sistema, imitando a los tarados dominadores, para recibir tal vez de ellos la limosna, si es que se acreditan lo suficiente" (Adorno, 1972e, 377). 


\section{BIBLIOGRAFÍA}

En algunos casos la traducción propia puede variar levemente de la traducción de la edición castellana citada.

Adorno, Th. W. (1970a [1964]): Jargon der Eigentlichkeit. Zur Deutschen Ideologie, en Gesammelte Schriften T. 6, ed. R. Tiedemann et al., Frankfurt a.M., Suhrkamp.

Adorno, Th. W. (1970b [1966]): Negative Dialektik, en Gesammelte Schriften T. 6, ed. R. Tiedemann et al., Frankfurt a.M., Suhrkamp.

Adorno, Th. W. (1972a [1951]): "Freudian Theory and the Pattern of Fascist Propaganda", en Gesammelte Schriften T. 8 , ed. R. Tiedemann et al., Frankfurt a.M., Suhrkamp, pp. 408-433.

Adorno, Th. W. (1972b [1955]): "Zum Verhältnis von Soziologie und Psychologie", en Gesammelte Schriften T. 8, ed. R. Tiedemann et al., Frankfurt a.M., Suhrkamp, pp. 42-85.

Adorno, Th. W. (1972c [1961]): "Über Statik und Dynamik als soziologische Kategorien", en Gesammelte Schriften T. 8, ed. R. Tiedemann et al., Frankfurt a.M., Suhrkamp, pp. 217-237.

Adorno, Th. W. (1972d [1959); "Theorie der Halbbildung", en Gesammelte Schriften T. 8, ed. R. Tiedemann et al., Frankfurt a.M., Suhrkamp, pp. 93-121.

Adorno, Th. W. (1972e [1942): "Reflexionen zur Klassentheorie", en Gesammelte Schriften T. 8, ed. R. Tiedemann et al., Frankfurt a.M., Suhrkamp, pp. 373391.

Adorno, Th. W. (1974a [1959]): "Zur Schlußszene des Faust", en Gesammelte Schriften T. 11, ed. R. Tiedemann et al., Frankfurt a.M., Suhrkamp, pp. 129-138.

Adorno, Th. W. (1974b [1961]): "Versuch, das Endspiel zu verstehen", en Gesammelte Schriften T. 11, ed. R. Tiedemann et al., Frankfurt a.M., Suhrkamp, pp. 281-321.

Adorno, Th. W. (1974c [1962]): "Engagement", en Gesammelte Schriften T. 11, ed. R. Tiedemann et al., Frankfurt a.M., Suhrkamp, pp. 409-430.

Adorno, Th. W. (1974d [1967]): "Offener Brief an Rolf Hochhuth", en Gesammelte Schriften T. 11, ed. R. Tiedemann et al., Frankfurt a.M., Suhrkamp, pp. 591-598.

Adorno, Th.W. (1977a [1953]): "Aufzeichnungen zu Kafka", en Gesammelte Schriften T. 10.1, ed. R. Tiedemann et al., Frankfurt a.M., Suhrkamp, pp. 254-287.

Adorno, Th. W. (1977b [1967]): "Erziehung nach Auschwitz", en Gesammelte Schriften T. 10.2, ed. R. Tiedemann et al., Frankfurt a.M., Suhrkamp, pp. 664-690.

Adorno, Th. W. (1977c [1969]): Stichworte. Kritische Modelle 2, en Gesammelte Schriften T. 10.2, ed. R. Tiedemann et al., Frankfurt a.M., Suhrkamp, pp. 595-799.

Adorno, Th. W. (1977d [1959]): "Was bedeutet: Aufarbeitung der Vergangenheit", en Gesammelte Schriften T. 10.2, ed. R. Tiedemann et al., Frankfurt a.M., Suhrkamp, pp. 555-572.

Adorno, Th. W. (1977e [1951]): "Aldous Huxley und die Utopie", en Gesammelte Schriften T. 10.2, ed. R. Tiedemann et al., Frankfurt a.M., Suhrkamp, pp. 97-122.

Adorno, Th. W. (1980 [1951]): Minima Moralia, en Gesammelte Schriften T. 4, ed. R. Tiedemann et al., Frankfurt a.M., Suhrkamp.

Adorno, Th. W. (1993 [1968]: Vorlesung zur Einleitung in die Soziologie, en Nachgelassene Schriften, IV. Vorlesungen, T. 15, ed. por Ch. Gödde, Frankfurt a.M., Suhrkamp.

Arendt, H. (1969): "Martin Heidegger ist achtzig Jahre alt", en Merkur, 258/10, pp. 893-902.
Arendt, H. (1971): "Thinking and Moral Considerations: A Lecture", en Social Research, 38/3, 417-446.

Arendt, H. (1981 [1951]): Los orígenes del totalitarismo, Madrid, Alianza.

Arendt, H. (1996): "La tradición y la época moderna", en Entre el pasado y el futuro. Ocho ejercicios sobre la reflexión política, trad. de Ana Poljak, Barcelona, Península.

Arendt, H. (2003): Eichmann en Jerusalén. Un estudio sobre la banalidad del mal, Barcelona, Lumen.

Arendt, H. (2004): La tradición oculta, Barcelona, Paidós.

Arendt, H. (2005a): Ensayos de comprensión 1930-1954, trad. A. Serrano de Haro, Madrid, Caparrós.

Arendt, H. (2005b): La condición humana, trad. R. Gil, introd. M. Cruz, Barcelona, Paidós.

Arendt, H. (2006a): Diario filosófico 19501973, 2 Vol., trad. R. Gabás, Barcelona, Herder.

Arendt, H. (2006b): Über das Böse. Eine Vorlesung zu Fragen der Ethik, ed. póst. por J. Kohn, trad. de U. Ludz, con un epilogo de F. Augstein. MünchenZürich, Piper.

Arendt, H./Blücher, H. (1996): Briefe 19361968, ed. por L. Köhler, München, Piper.

Arendt, H./Blumenfeld, K. (1995): “...in keinem Besitz verwurzelt". Die Korrespondenz. Ed. por I. Nordmann y I. Pilling, Hamburg, Rotbuch Verlag.

Arendt, H./Heidegger, M. (1998): Briefe 1925-1975, Frankfurt am Main, Vittorio Klostermann. Arendt, H./Jaspers, K. (1993): Briefwechsel 1926-1969, ed. por L. Köhler, München, Piper.

Auer, D. (2003): "Paria wider Willen. Adornos und Arendts Reflexionen auf den Ort des Intellektuellen", en D. Auer/L. Rensmann/J. Schulze Wessel (eds.), Arendt und Adorno, Frankfurt a.M., Suhrkamp, pp. 35-56. 
Bauman, Z. (1997): Modernidad y Holocausto, Madrid, Sequitur.

Benhabib, Sheila (2006): "Denn sie war ein freier Mensch. Hannah Arendt, die Philosophin des 20. Jahrhunderts", en Die Zeit, 12 de oct., pp. 59-60.

Benjamin, W. (1972 [1940]): "Über den Begriff der Geschichte", en Gesammelte Schriften T. I, ed. R. Tiedemann, Frankfurt a.M., Suhrkamp, pp. 691-704.

Birulés, F. (2006): "El totalitarismo, una realidad que desafía la compresión", en M. Cruz (comp.): El siglo de Hannah Arendt, Barcelona, Paidós, pp. 37-61.

Brumlik, M. (2006): "Ein doppelter Geburtstagsgruß. Hannah Arendt und den 'Blättern' gewidmet", en Blätter für deutsche und internationale Politik, 12, pp. 1480-1490.

Claussen, D.(1987): Grenzen derAufklärung. Zur gesellschaftlichen Geschichte des modernen Antisemitismus, Frankfuert a.M., Fischer.

Claussen, D. (1988): "Nach Auschwitz. Ein Essay über die Aktualität Adornos", en: D. Diner (ed.), Zivilisationsbruch. Denken nach Auschwitz, Frankfurt a.M., Fischer, pp. 54-68.

Forti, S. (2008): El totalitarismo: trayectoria de una idea límite, Barcelona, Herder.

Friedrich, C. J. (1957): Totalitäre Diktatur (col. de Z. Brzezinski), Stuttgart, Kohlhammer.

Ganzfried, D./Hefti, S. (eds.) (1997): Hannah Arendt - Nach dem Totalitarismus, Hamburg, EVA.

Grunenberg, A. (2006): Hannah Arendt und Martin Heidegger. Geschichte einer Liebe, München/Zürich, Piper.

Heuer, W. (1997): "Ein schwieriger Dialog. Die Hannah Arendt-Rezeption im deutschsprachigen Raum", en D. Granzfried/S. Hefti (eds.), pp. 21-28.

Himmler, H. (1974) Geheimreden 1933 bis 1945 und andere Ansprachen, ed. por B. F. Smith y A. F. Peterson, Frankfurt a.M. Berlin y Wienn, Propyläen Verlag.
Horkheiner, M./Adorno, Th. W. (1996 [1956]): "Vorwort zu Paul W. Massing, Vorgeschichte des politischen Antisemitismus", en Th. W. Adorno: Gesammelte Schriften T. 20.2, ed. R. Tiedemann et al., Frankfurt a.M., Suhrkamp, pp. 650-653.

Horkheimer, M./Adorno, Th. W. (1981 [1947]): Dialektik der Aufklärung. Philosophische Fragmente, en Th. W. Adorno: Gesammelte Schriften T. 3, ed. R. Tiedemann et al., Frankfurt a.M., Suhrkamp.

Horkheimer, M. et all. (1981): Wirtschaft, Recht und Staat im Nationalsozialismus. Analysen des Instituts für Sozialforschung 1939-1942, eds. H. Dubiel A. Söllner, Frankfurt a.M. Europäische Verl.-Anst.

Kristeva, J. (2001): Hannah Arendt. "The Banality of Evil", New York, Columbia University Press.

Marrades, J. (2002): "La radicalidad del mal banal", en LOGOS. Anales del Seminario de Metafísica, 35, 79-103.

Marti, U. (1997): "Totales Herrschaftsanspruch und Entpolitisierung. Hannah Arendt und die 'kapitalistische Genealogie' des Totalitarismus", en Ganzfried, D./Hefti, S. (eds.) (1997), pp. 68-75.

Schlangen, W. (1976): Die TotalitarismusTheorie. Entwicklung und Probleme, Kohlhammer, Stuttgart et. all.

Schmid Noerr, G. (1990): Das Eingedenken der Natur im Subjekt. Zur Dialektik von Vernunft und Natur in der Kritischen Theorie Horkheimers, Adornos und Marcuse. Darmstadt, WBG.

Schmidt, A. (1978): Der Begriff der Natur in der Lehre von Marx, 3. ${ }^{\text {a }}$ ed., Frankfurt a.M./Köln, EVA.

Schmidt, A. (1987): "Die in Naturgeschichte verstrickte Menschheit", en G. Schweppenhäuser et al. (ed.): Krise und Kritik. Zur Aktualität der Marxs- chen Theorie, T. 1, Lüneburg, zu Klampen, pp. 9-12.

Schulze Wessel, J./Rensmann/L. (2003): "Radikalisierung oder 'Verschwinden' der Judenfeindschaft? Arendts und Adornos Theorien zum modernen Antisemitismus", en D. Auer/L. Rensmann/J. Schulze Wessel (eds.), Arendt und Adorno, Frankfurt a.M., Suhrkamp, pp. 97-129.

Schulze Wessel, J. (2006): Ideologie der Sachlichkeit. Hannah Arendts politische Theorie des Antisemitismus, Frankfurt a.M., Suhrkamp.

Smith, G. (ed., 2000): Hannah Arendt Revisited: "Eichmann in Jerusalem" und die Folgen, Frankfurt a.M., Suhrkamp.

Sofsky, W. (1993): Die Ordnung des Terrors. Das Konzentrationslager, Frankfurt a.M., Fischer.

Traverso, E (2001): La historia desgarrada. Ensayo sobre Auschwitz y los intelectuales, Barcelona, Herder.

Vicchiarelli Scott, J. (2003): "Die amerikanische Erfahrung. Adorno, Arendt und das Exil in den USA", en D. Auer/L. Rensmann/J. Schulze Wessel (eds.), Arendt und Adorno, Frankfurt a.M., Suhrkamp, pp. 57-73.

Villa, D. (2007): "Genealogies of Total Domination: Arendt, Adorno, and Auschwitz", en New German Critique, 100, 1-45.

Weber, M. (1971 [1921]): Wirtschaft und

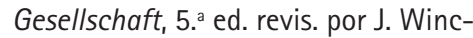
kelmann. Tübingen, Mohr.

Zamora, J. A. (2004): Th. W. Adorno: Pensar contra la barbarie, Madrid, Trotta.

Zamora, J. A. (2007): "El enigma de la docilidad: Teoria de la sociedad y psicoanálisis en Th. W. Adorno", en M. Cabot (ed.), El pensamiento de Th. W. Adorno. Balance y perspectivas. Palma: Universitat de les Illes Balears, pp. 27-42.

Zuckermann, M. (2007): "Zur Bedeutung von Hannah Arendts 'Eichmann in Jerusalem'", en UTOPIE kreativ, 201/2002, julio-agosto, 674-680. 